\title{
Pandemija COVID-19 mijenja uobičajen pristup u nadzoru nad dobrom proizvođačkom praksom
}

\author{
T. Kolonić, M. Bencetić Marijanović i S. Tomić*
}

https://doi.org/10.15255/KUI.2020.061 KUI-33/2021

Stručni rad

Prispjelo 3. rujna 2020.

Prihvaćeno 1. Listopada 2020.

Agencija za lijekove i medicinske proizvode (HALMED), Ksaverska cesta 4, 10000 Zagreb

\begin{abstract}
Sažetak
Dobra proizvođačka praksa (GMP) je skup različitih smjernica, pravila i normi koje jamče učinkovitost, kvalitetu, sigurnost i dosljednost u proizvodnji i kontroli lijekova. Nadzor nad dobrom proizvođačkom praksom u Hrvatskoj provodi Agencija za lijekove i medicinske proizvode (HALMED). U svrhu održavanja konzistentnih inspekcijskih standarda, HALMED ima razvijen Poslovnik kakvoće izrađen u skladu s europskim smjernicama. Inspektori Agencije imaju odgovarajuća znanja i iskustvo te se trajno usavršavaju. Po obavljenoj inspekciji, HALMED izdaje proizvodnu dozvolu i potvrdu o provođenje dobre proizvođačke prakse (GMP potvrdu) za proizvođače u Republici Hrvatskoj te GMP potvrdu za proizvođače iz trećih zemalja. S obzirom na nemogućnost izlaska inspektora na teren uslijed pandemijske situacije, sve se češće pribjegava ocjeni na daljinu.
\end{abstract}

Ključne riječi

Agencija za lijekove i medicinske proizvode, nadzor, dobra proizvođačka praksa, proizvodna dozvola, nedostatci

\section{Uvod}

Moderna proizvodnja lijekova nezamisliva je bez pridržavanja načela dobre proizvođačke prakse (GMP). To je skup normi koje osiguravaju da se djelatne tvari i gotovi lijekovi proizvode na konzistentan i sljediv način i u skladu s njihovom namjenom te da se njihova kakvoća provjerava u skladu sa zahtjevima kakvoće (specifikacijom). Farmaceutski proizvođači zakonski su obvezni primjenjivati GMP standarde. ${ }^{1}$ Svrha GMP-a je smanjiti mogući rizik u kakvoći lijeka koji bi mogao imati štetan utjecaj na zdravlje pacijenta. GMP je u Hrvatskoj reguliran odgovarajućim zakonskim $^{1}$ i podzakonskim propisima ${ }^{2,3}$ kao i propisima na razini EU-a. ${ }^{4,5}$ Inspekcijski nadzor nad proizvođačima lijekova za humanu i veterinarsku uporabu provode nadležna regulatorna tijela za lijekove država članica EU-a. U Hrvatskoj je to Agencija za lijekove i medicinske proizvode (HALMED) kao državna ustanova s javnim ovlastima. Povijesni put preuzimanja te ovlasti od ministarstva nadležnog za zdravstvo bio je dug i mukotrpan. Prvi puta je prenesena 2003. godine s Ministarstva na HALMED, ${ }^{6}$ da bi 2004., pod neobjašnjivim okolnostima, ponovo bila vraćena u Ministarstvo. ${ }^{7}$

Međutim, ulazak Republike Hrvatske 2013. u Europsku uniju i sve veći zahtjevi za stručnim resursima u svrhu ispunjavanja preuzetih obveza iz pravne stečevine na polju nadzora GMP-a ponukali su nadležno ministarstvo da tu ovlast, kao i nadzor nad farmakovigilancijom potpuno prenese na HALMED. Isto tako, česte vanjske evaluacije, kao i zahtjevi proizvođača veterinarskih lijekova s proizvodnim mjestima u Hrvatskoj potakli su i Ministarstvo poljoprivrede da ovlast nadzora nad GMP-om za veterinarske lijekove prenese na HALMED. ${ }^{8}$ Na taj su način svi poslovi vezani za

*Autor za dopisivanje: prof. dr. sc. Siniša Tomić

e-pošta: sinisa.tomic@halmed.hr nadzor nad proizvodnjom te izdavanjem proizvodnih dozvola i potvrda o provođenju dobre proizvođačke prakse objedinjeni u jednom nadležnom tijelu. Većina djelatnih tvari koje se ugrađuju u gotove lijekove na europskom tržištu dolazi iz trećih zemalja, mahom iz jugoistočne Azije, a na proizvođačima lijekova je dužnost da osiguraju i upotrebljavaju samo djelatnu tvar proizvedenu u skladu s dobrom proizvođačkom praksom. Proizvođači lijekova moraju imati GMP potvrdu, što znači da proizvodna mjesta proizvođača tih zemalja moraju prethodno biti inspicirana od neke od država članica EU-a, kako bi njihovi lijekovi mogli biti plasirani na europsko tržište.

Isto tako i nedavna pojava nitrozaminskih onečišćenja, kao potencijalnih karcinogena u nekim sartanima, ${ }^{9}$ a kasnije i u nekim drugim lijekovima (ranitidin, metformin) ${ }^{10,11}$ te p-kloroanilina u nekim oblicima paracetamola, ${ }^{12}$ predstavljaju globalni izazov za proizvođače te regulatorna tijela u postizanju načela moderne dobre proizvođačke prakse i nadzora nad njihovim provođenjem. Dodatnu otegotnu okolnost predstavlja i pandemija uzrokovana virusom COVID-19, gdje u većini slučajeva zbog intenzivnog širenja bolesti u tim zemljama nije preporučen izlazak inspektora na teren, već se pribjegava tzv. ocjeni na daljinu (engl. distant assessment), koja u svakom slučaju ne može u potpunosti nadomjestiti fizički nadzor na proizvodnom mjestu.

\section{HALMED-ov odsjek za inspekcijske poslove (inspektorat)}

HALMED je osnovan 2003., kao nadležno regulatorno tijelo za lijekove i medicinske proizvode. ${ }^{6}$ Djelatnosti koje obavlja su ocjena i davanje odobrenja za stavljanje lijekova u promet te njihova izmjena i obnova, laboratorijska pro- 
vjera kakvoće humanih i veterinarskih lijekova uzorkovanih s tržišta, praćenje nuspojava lijekova, davanje stručnog savjeta u pogledu razvoja lijeka, davanje suglasnosti za unos/ uvoz lijekova koji nemaju odobrenje u Hrvatskoj, ali imaju u drugim članicama EU-a, davanje dozvola za otvaranje specijaliziranih prodavaonica za lijekove i medicinske proizvode, vigilancija medicinskih proizvoda, izrada monografija za Hrvatsku farmakopeju, izračun najviše dozvoljene cijene lijeka, praćenje potrošnje lijekova i promicanje racionalne farmakoterapije, nadzor nad farmakovigilancijom te nadzor nad dobrom proizvođačkom praksom za lijekove za humanu i veterinarsku uporabu te davanje proizvodne dozvole. Poslovi vezani za nadzor dobre prakse u prometu lijekova (GDP), dobre laboratorijske prakse (GLP), dobre kliničke prakse (GCP) i odobravanja kliničkih ispitivanja i dalje su u nadležnosti Ministarstva zdravstva. ${ }^{13-16}$

Ustrojstvena jedinica HALMED-a nadležna za poslove nadzora nad dobrom proizvođačkom praksom te izdavanjem dozvola je Odsjek za inspekcijske poslove, koji je sastavni dio Odjela za sigurnu primjenu lijekova i medicinskih proizvoda kao šire ustrojstvene jedinice koja još obuhvaća i farmakovigilanciju te vigilanciju medicinskih proizvoda te praćenje neispravnosti u kakvoći lijeka kao aktivnosti nadzora tržišta bitnih za praćenje sigurnosti proizvoda za zdravstvo u prometu i zaštiti pacijenta. HALMED na razini cijele ustanove ima razvijen sustav kakvoće od kojeg se posebni Poslovnik kakvoće odnosi na Odsjek za inspekcijske poslove. Poslovnik kakvoće koji se odnosi na GMP inspekciju izrađen je te održavan i ažuriran u skladu s europskim smjernicama i odgovarajućim ISO i EN normama. ${ }^{17}$ Primarna svrha Poslovnika kakvoće je opisati i propisati sustav u svrhu osiguranja održavanje odgovarajućih standarda kakvoće. Svrha usvajanja zajedničkih standarda sustava kakvoće je uspostava konzistentnih inspekcijskih standarda između GMP inspektorata država članica te olakšavanje uzajamnog priznavanja njihovih inspekcijskih izvješća.

Radi održavanja funkcionalnog sustava kakvoće Odsjek surađuje i razmjenjuje informacije s relevantnim inspektoratima drugih država članica, Europskom komisijom, Europskom agencijom za lijekove (EMA) i Farmaceutsko-inspekcijsko-kooperacijskom shemom (PIC/S). ${ }^{18}$ Osoblje koje radi u inspektoratu mora biti bez ikakvog sukoba interesa koji bi na bilo koji način mogao utjecati na njihovo stručno ocjenjivanje i slobodu u donošenju odluka. Stoga su pravila etike, deontologije i sukoba interesa strogo definirani internim aktima HALMED-a. Odgovornosti i ovlasti pojedinog osoblja jasno su hijerarhizirane, opisane i dokumentirane u Pravilniku o unutarnjoj organizaciji i sistematizaciji. Radi učinkovitog postizanja ciljeva Odsjek ima odgovarajuće resurse na svim razinama. Također, postoji sustav periodičke upravine ocjene koja se provodi kroz unutarnji nadzor nad sustavom kakvoće. Na taj način se sustavno kontroliraju svi dokumenti (npr. SOP-ovi) koji su relevantni za provođenje nadzora. Nužno je da su aktualne verzije SOP-ova potpisale ovlaštene osobe i stavljene na snagu te da su one verzije koje su izvan snage na odgovarajući način pohranjene i čuvane kroz definirano vremensko razdoblje. Sve izmjene u dokumentaciji provode se na kontroliran način i potpisuju ih za to ovlaštene osobe. Uspostavljen je odgovarajući sustav arhiviranja i zaprimanja dokumentacije, što uključuje podnositelje zahtjeva kao i nositelje odgovarajućih dozvola. Nakon provođenja GMP nadzora HALMED izdaje odgovarajuće izvješće u skladu sa zahtjevima Europske komisije, a potom i proizvodne dozvole, odnosno GMP potvrde. Ako je više GMP inspektora uključeno u nadzor, potrebno je imenovati vodećeg inspektora (engl. lead), koji u tom slučaju koordinira izradu inspekcijskog izvješća i usuglašava ga s ostalim članovima inspekcijskog tima. Odsjek ima izrađene i indikatore praćenja kvalitete rada koji uključuju poštivanje zakonskih rokova u provođenju određenih postupaka, urednost zapisa i dokumentacije, postizanje zadanih ciljeva te ispunjenje godišnjeg plana inspekcija.

\section{Inspektori}

Inspektori koji provode GMP nadzor moraju imati odgovarajuće iskustvo, edukacije i kvalifikacije. Poslove inspektora HALMED-a mogu obavljati osobe sa završenim preddiplomskim i diplomskim sveučilišnim studijem ili integriranim preddiplomskim i diplomskim sveučilišnim studijem zdravstvenog ili drugog odgovarajućeg usmjerenja, s tri godine radnoga iskustva na odgovarajućim poslovima. Preporučljivo je da inspektori posjeduju znanja i kvalifikacije propisane za odgovornu osobu za puštanje serije lijeka u promet. Odgovorna osoba za puštanje serije lijeka u promet $(\mathrm{QP})$ je osoba koja ispunjava uvjete propisane člankom 49. Direktive 2001/83/EZ,1,4 što za inspektore i QP uključuje da trebaju imati završen jedan od sljedećih preddiplomskih i diplomskih sveučilišnih studija ili integriranih preddiplomskih i diplomskih sveučilišnih studija: farmacija, medicina, veterina, kemija, farmaceutska kemija i tehnologija i biologija. Nadalje, program studija mora obuhvatiti znanja iz: eksperimentalne fizike, opće i anorganske kemije, organske kemije, analitičke kemije, farmaceutske kemije uključujući ispitivanje lijekova, opće i primijenjene (medicinske) biokemije, fiziologije, mikrobiologije, farmakologije, farmaceutske tehnologije, toksikologije, farmakognozije (sastav i djelovanje djelatnih tvari biljnog i životinjskog podrijetla). ${ }^{17}$ Odgovorna osoba za puštanje serije lijeka u promet obvezna je osigurati da je svaka serija lijeka proizvedena i provjerena sukladno važećim propisima i podatcima navedenim u dokumentaciji priloženoj uz zahtjev za davanje odobrenja za stavljanje lijeka u promet. Ako se radi o lijekovima uvezenim iz trećih zemalja, obvezna je osigurati da je za svaku uvezenu seriju lijeka provedena u zemlji uvoznici potpuna provjera kakvoće te da serije lijeka u promet namijenjene tržištu Europske unije na svojem pakovanju imaju sigurnosnu oznaku. Isto tako, odgovorna osoba svojim potpisom u poseban očevidnik odobrava puštanje pojedine serije lijeka u promet.

Pored navedenih uvjeta za odgovornu osobu za puštanje serije lijeka u promet i prije nego što budu imenovani inspektorom, kandidati moraju biti educirani iz sljedećih područja: europsko i hrvatsko zakonodavstvo za lijekove s posebnim težištem na dobru proizvođačku praksu i dobru praksu u prometu na veliko, načela osiguranja kvalitete, sustav upravljanja kvalitetom (sukladno normi ISO 2000:9000), poznavanje proizvodnje djelatnih tvari i gotovih lijekova (npr. oblikovanje lijekova, procesno i ventilacijsko inženjerstvo, validacija, računalni sustavi, analitička oprema, mikrobiološka čistoća), poznavanje tehnologije 
koja se primjenjuje u proizvodnji lijekova te operativnih postupaka i isporuke usluge odnosno proizvoda, načine na koji se lijek upotrebljava, moguće nedostatke u kakvoći koji se mogu pojaviti tijekom proizvodnih postupaka ili tijekom uporabe lijeka. Isto tako, moraju znati protumačiti utjecaj pronađenih odstupanja u proizvodnom postupku na isporuku i uporabu samog lijeka.

Zatim, isto tako, trebaju poznavati sustav kakvoće unutar HALMED-a i svoje ustrojstvene jedinice te postupati u skladu s uputama opisanim u relevantnim standardnim operativnim postupcima (SOP). Sljedeća znanja koja moraju imati odnose se na povezanost GMP-a i postupaka davanja odobrenja za stavljanje gotovog lijeka u promet, na međusobnu povezanost davanja proizvodnih dozvola, nadzora i uzorkovanja. Potrebno je poznavati europske sporazume o uzajamnom priznavanju inspekcija s određenim trećim državama (npr. SAD, Kanada), imati dobre sposobnosti suradnje i komunikacije informacija s drugim nadležnim tijelima na nacionalnoj, europskoj i međunarodnoj razini, zatim poznavati strukturu i funkcioniranje trgovačkih društava. Isto tako potrebno je poznavati inspekcijske tehnike koje se uče na specijaliziranim tečajevima, ili prigodom inspekcija na samom proizvodnom mjestu uz mentorstvo iskusnog inspektora. Potrebno je poznavati administrativne postupke važne za provođenje inspekcije koji uključuju planiranja i određivanja prioritetnih inspekcija i njihovih nalaza, pripreme, vođenja, koordiniranja, izvješćivanja, praćenja i davanja povratnih informacija inspiciranoj strani te pohranjivanja i arhiviranja dokumentacije.

Nakon raspoređivanja na radno mjesto, pored svojeg stečenog znanja i kvalifikacija, novi inspektori u HALMED-u prolaze početni teorijski dio edukacije kao i praktični i to u početku samo kao promatrači u inspekcijama u Hrvatskoj i drugim zemljama pod vodstvom iskusnog inspektora - mentora, gdje se kroz sam nadzor rješavaju konkretna pitanja i pojašnjavaju ciljevi inspekcije. S obzirom na okolnosti brzog razvoja modernih tehnologija, sve češću uporabu automatiziranih i računalnih sustava u proizvodnji i kontroli kakvoće lijekova, inspektori prolaze cjeloživotno učenje, sudjelovanjem na tečajevima, seminarima, konferencijama i sastancima u zemlji i inozemstvu. Ako je moguće, dobro je da novi inspektori sudjeluju i u nadzorima s inspektorima iz drugih članica EU-a i na taj način stječu relevantno iskustvo. Glavne odlike inspektora su objektivnost, profesionalni integritet, stručne kompetencije i inspekcijske vještine.

\section{Provođenje GMP nadzora}

Nadzor nad dobrom proizvođačkom praksom može obuhvatiti cjelovit ili djelomičan nadzor, u svrhu utvrđivanja poštuju li proizvođač ili uvoznik pri proizvodnji, uvozu i kontroli kakvoće zahtjeve dobre proizvođačke prakse. GMP nadzor obuhvaća provedbu inspekcije proizvođača i/ili uvoznika gotovih lijekova za primjenu kod ljudi i životinja, lijekova koji su u kliničkom ispitivanju (ispitivani lijekovi), djelatnih te pomoćnih tvari. Inspekcijski nadzor (inspekcija) podrazumijeva cjelovit postupak, od pripreme same inspekcije do izdavanja izlaznih dokumenata uključujući provedbu očevida na mjestu proizvodnje ili uvoza lijeka. Postoje dvije vrste inspekcije: redovna i izvanredna. Redovna inspekcija može biti inicijalno planirana u okviru HALMED-ovog godišnjeg programa inspekcija, a može biti i ad hoc planirana, ako je zahtjev od proizvođača ili nekog drugog europskog tijela zaprimljen naknadno. Inspekcija može biti i izvanredna i ona obično proizlazi uslijed incidentnih situacija, prijava sumnji na neispravnosti u kakvoći proizvoda, žurnog uzbunjivanja, sumnji na pojavu krivotvorenog lijeka u opskrbnom lancu, značajnih reklamacija te drugih izvanrednih situacija. Pokretanje inspekcije može biti temeljem HALMED-ova godišnjeg programa GMP inspekcija koji uključuje nadzor nad ispunjavanjem uvjeta dobre proizvođačke prakse ili temeljem zahtjeva podnositelja zahtjeva.

Podnositelj zahtjeva je fizička ili pravna osoba sa sjedištem u Republici Hrvatskoj koja traži od HALMED-a izdavanje proizvodne ili uvozne dozvole ili izmjenu/ukidanje postojećih dozvola ili izdavanje potvrde o provođenju dobre proizvođačke prakse (GMP potvrde). Zahtjev može pokrenuti i Ministarstvo zdravstva, Ministarstvo poljoprivrede, Europska komisija ili EMA, CHMP, EDQM, WHO i druge nacionalne i međunarodne ustanove. Proizvođači iz trećih država koji žele svoje lijekove i tvari za farmaceutsku uporabu plasirati na europsko tržište podnose zahtjev u svrhu dobivanja GMP potvrde, nakon provedene inspekcije, putem zastupnika u EU-u. HALMED može pokrenuti inspekciju ako se u postupku davanja odobrenja za stavljanje lijeka u promet ne može utvrditi da proizvođači i uvoznici lijekova iz trećih zemalja udovoljavaju uvjetima dobre proizvođačke prakse ili radi provedbe follow up inspekcije u svrhu pregleda otklanjanja nedostataka nakon inicijalno provedene inspekcije. U slučaju prijava neispravnosti u kakvoći te pojave signala proizašlih iz prijava nuspojava ili ako postoji sumnja na krivotvorinu, pokreće se izvanredna inspekcija. Inspekcija HALMED-a provodi redovni nadzor proizvođača i uvoznika lijekova prema godišnjem programu inspekcija koji se izrađuje temeljem procjene rizika.

Postupak GMP inspekcije sastoji se od pripremnog i provedbenog dijela (slika 1) te izvješćivanju o nalazima inspekcije i praćenju nedostataka (slika 2).

U pripremnom dijelu zaduženi inspektor upoznaje se $\mathrm{s}$ predmetom i potvrđuje opravdanost i vjerodostojnost podataka iz zahtjeva za provođenje inspekcije. U tom smislu pregledava glavni spis o mjestu proizvodnje (Site Master File), proizvedene/uvezene lijekove inspiciranog proizvođača ako postoje izvješća prethodnih inspekcija te eventualne korektivne i preventivne mjere (CAPA), povučene lijekove s tržišta u proteklom razdoblju, prijave sumnji u kakvoću ili znakove neuobičajenih pojava. Zatim pregledava važeće proizvodne dozvole i GMP potvrde, relevantne dijelove dokumentacije (CTD) u postupku davanja odobrenja, informacije iz baza drugih regulatornih tijela (EudraGMDP, FDA pisma upozorenja), podatke o izmjeni opreme, proizvodnih postupaka i ključnog osoblja proizvođača, interne postupke zatražene od podnositelja zahtjeva, standarde, smjernice i ostalu relevantnu literaturu. Dok planirane GMP inspekcije mogu biti unaprijed najavljene inspiciranoj strani ili se mogu provoditi nenajavljeno, ovisno o procjeni, izvanredne GMP inspekcije se provode bez prethodnog najavljivanja kako svojom najavom ne bi ugrozile svrhu i područje inspekcije. 


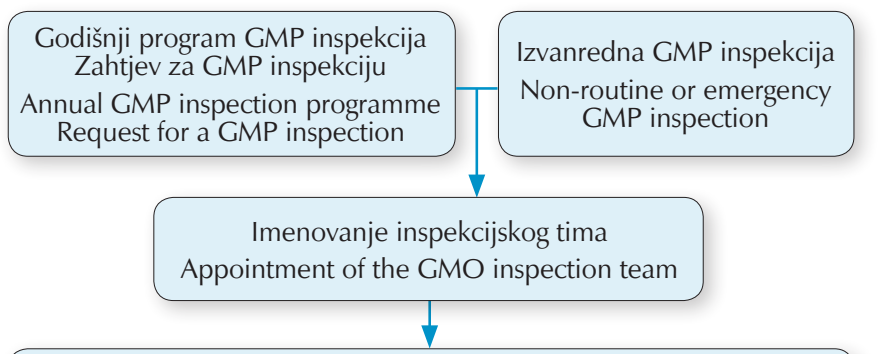

Priprema za inspekciju, izrada plana inspekcije

Unos u EudraGMDP planning module, ako je primjenjivo Preparation for inspection and preparing an inspection agenda Entry of data into EudraGMDP planning module, if applicable

Zaključak o osnivanju povjerenstva

Letter of authorisation to carry out GMP inspection

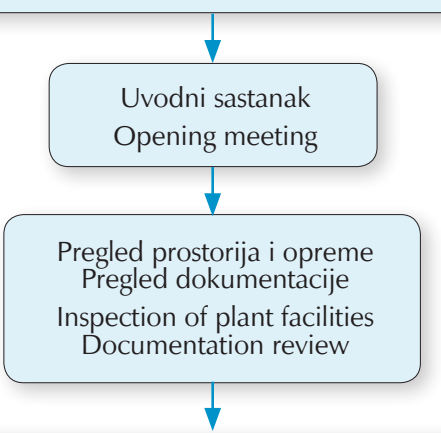

Završni sastanak

Zapisnik/usmena komunikacija nedostataka Final meeting

Inspection record/identified deficiencies presented orally

Slika 1 - Pripremni i provedbeni dio inspekcije

Fig. 1 - Preparation and conducting the inspection

Inspektori pregledavaju proizvodni pogon i mjesta proizvodnje najčešće slijede logični tijek polaznih materijala, od skladišta za prijem polaznih materijala, kroz proizvodni prostor, prostor kontrole kakvoće do skladišta za puštene serije gotovih proizvode, uzimajući u obzir smjernice dobre proizvođačke prakse.

Detaljan pregled proizvodnog pogona provodi se kako bi se utvrdilo jesu li objekti i oprema izvedeni i dizajnirani na primjeren način za namijenjene operacije te provode li se procesi sukladno definiranim procedurama $i$ validiranim postupcima. U nekim slučajevima potrebno je provesti pregled prostorija i opreme neposredno nakon dolaska na mjesto inspekcije. Provođenje inspekcije temelji se i na procjeni rizika na mjestu proizvodnje koja uključuje traženje signala tijekom pregleda proizvodnog pogona ili pregleda dokumentacije koji mogu ukazati na probleme s proizvodom, proizvodnim postupkom ili sustavom. Na ta se područja potrebno usredotočiti i pritom imati fleksibilan plan inspekcije. Isto tako, svaka identifikacija visokog rizika za vrijeme očevida može dovesti do promjena u planu inspekcije i fokusa na problematična područja.

Ako se tijekom pregleda mjesta inspekcije pokaže da pojedini dio proizvodnog procesa predstavlja veći rizik, potrebno je procijeniti rizik i više se koncentrirati na taj specifični dio u procesu te evidentirati eventualna odstupanja. Tijekom inspekcije inspektor/i raspravljaju primjedbe s ključnim, rukovodećim i tehničkim osobljem kako bi se utvrdilo činjenično stanje i nedostatci. Time inspektori ocjenjuju znanje i stručnost osoblja. Inspektori također ocjenjuju cjelokupni sustav vođenja dokumentacije (bilo u elektroničkom ili papirnatom obliku), uključujući zahtjeve kakvoće za proizvod/lijek (specifikacije), proizvodne recepture, upute za proizvodnju i postupke opremanja proizvoda, radne postupke i zapise koji pokrivaju različite proizvodne postupke, dokumente kontrole kakvoće i druge relevantne dokumente sustava kakvoće, SOP-ove, ugovorni rad, uzorkovanje, reklamacije i povlačenja lijeka. Inspektori pregledavaju dokumentaciju po fazama proizvodnje te cjelovitu dokumentaciju o seriji lijeka.

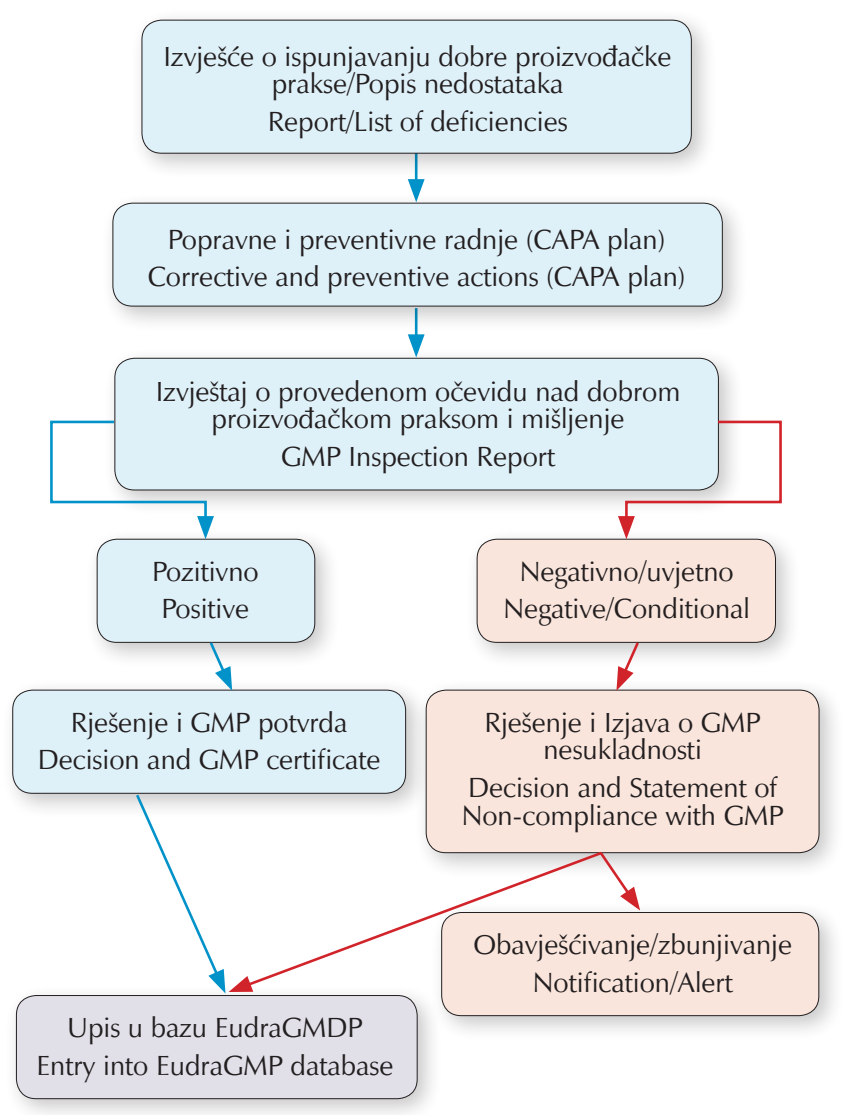

Slika 2 - Izvješćivanje o nalazima inspekcije i praćenje nedostataka

Fig. 2 - Reporting on inspection findings and follow up of deficiencies

Svaku primjedbu na dokumentaciju inspektor evidentira tijekom postupka te vodi zapisnik u svrhu cjelovitog prikupljanja svih relevantnih informacija temeljem kojih će inspekcijski tim dati izvješće i mišljenje o ispunjavanju GMP uvjeta, kao i evidentiranje svih dokaza. Ako ih je bilo, u zapisnik se uvode utvrđeni nedostatci koji mogu biti kritični, značajni i ostali. Kritični nedostatak proizveo je ili dovodi do značajnog rizika u proizvodnji lijeka koji je štetan za pacijenta ili lijeka za životinje koji bi mogao rezultirati štetnim reziduama u životinjama namijenjenim prehrani 
ljudi. Značajan nedostatak ukazuje na znatno odstupanje od smjernica dobre proizvođačke prakse propisane hrvatskim i europskim zakonodavstvom, a može proizvesti lijek koji nije u skladu s odobrenjem za stavljanje lijeka u promet ili ukazuje na znatno odstupanje od uvjeta odobrenih proizvodnom dozvolom. Ukoliko se nedostatak ne može klasificirati kao kritični ili značajni, svrstava se u kategoriju ostalih nedostataka. Nakon provedene inspekcije inspektori izrađuju izvješće, odnosno List of deficiencies za treće zemlje, koje sadrži klasificirane nedostatke povezane s relevantnim standardima i smjernicama, koje u roku od 30 dana dostavljaju inspiciranoj strani. Ako su tijekom inspekcije utvrđeni nedostatci, inspicirana strana treba, unutar 30 dana od provedbe inspekcije, HALMED-u dostaviti očitovanje i CAPA plan.

U slučaju kritičnih nedostataka i utvrđenog neispunjavanja uvjeta dobre proizvođačke prakse inspektori mogu izdati usmeno rješenje na licu mjesta tijekom provedbe očevida i odmah narediti uklanjanje nedostataka te pristupiti davanju Izjave o neispunjavanju uvjeta dobre proizvođačke prakse ili poduzeti bilo koju drugu mjeru sukladno zakonskim ovlastima (npr. donijeti odluku o ukidanju proizvodne dozvole, ukidanju ili suspendiranju rješenja za stavljanje lijeka u promet, narediti povlačenje lijeka/djelatne tvari/ pomoćne tvari iz prometa ili obustavu njihova isporučivanja na teritoriju Republike Hrvatske, odnosno propisati druge regulatorne mjere). ${ }^{19-23} \mathrm{Na}$ temelju provedene inspekcije, izvješća i dostavljenog očitovanja o nedostatcima, inspektor izrađuje završni izvještaj i mišljenje o ispunjavanju uvjeta dobre proizvođačke prakse, temeljem kojeg se izdaje rješenje o davanju/ uskraćivanju/ izmjeni/ ukidanju proizvodne dozvole, rješenje o davanju ili uskraćivanju upisa/izmjene upisa u očevidnik ili rješenje o brisanju iz očevidnika proizvođača, uvoznika i veleprodaja djelatnih i/ili pomoćnih tvari, ili davanju potvrde o provođenju dobre proizvođačke prakse (GMP potvrda), odnosno u slučaju neispunjavanja uvjeta izdaje se Rješenje i Izjava o neispunjavanju uvjeta dobre proizvođačke prakse (engl. Non-Compliance). Rješenje i Potvrda o provođenju dobre proizvođačke prakse daju se na rok od 3 godine od dana provedene inspekcije, koji se temeljem procjene rizika može produljiti ili skratiti.

Podatke o izdanim proizvodnim dozvolama, upisu u očevidnik proizvođača, uvoznika i veleprodaja djelatnih tvari te potvrdama o provođenju dobre proizvođačke prakse HALMED unosi u bazu podataka EudraGMDP te provodi odgovarajuće izmjene i ažuriranje podataka u toj bazi. Ako se uslijed nekog rizika za HALMED-ove inspektore, kao što je slučaj zbog pandemije COVIDOM-19, fizička inspekcija ne može provesti, moguće je provesti postupak ograničenog nadzora koji obuhvaća ocjenu na daljinu (engl. distant assessment). Taj se postupak provodi temeljem ocjene dokumentacije te dokumentiranog razgovora s proizvođačem na dovoljno informativan način u svrhu procjene usklađenosti dotičnog proizvodnog mjesta s dobrom proizvođačkom praksom. Ocjenu na daljinu treba izbjegavati u slučajevima kada određeno proizvodno mjesto nije nikada prije bilo fizički inspicirano, kada se radi o sterilnoj proizvodnji ili vrlo složenoj vrsti proizvodnje te ju ne bi trebalo provoditi više od jedanput.

\section{Zaključak}

Nadzor nad dobrom proizvođačkom praksom proizvođača lijekova za humanu i veterinarsku uporabu u Hrvatskoj je od 2019. godine objedinjen u HALMED-u kao jedinstvenom nadležnom tijelu, što je u skladu danas s većinom država članica EU-a te EMA-om, jer zdravlje životinja utječe i na zdravlje ljudi. U HALMED-u je ustrojena posebna jedinica, Odsjek za inspekcijske poslove, koja provodi GMP nadzor te nadzor nad farmakovigilancijom što, s obzirom na velik priliv novih znanstvenih i tehnoloških spoznaja, od poslodavca zahtijeva ulaganja u trajno usavršavanje inspektora u tim područjima. Velik broj djelatnih tvari i gotovih lijekova koji iz trećih zemalja dolaze na europsko tržište predstavljaju zahtjev za inspekcijske kapacitete država članica s obzirom na to da je prije izdavanja europske potvrde o dobroj proizvođačkoj praksi koje izdaju nadležne agencije država članica EU-a, proizvodna mjesta u tim zemljama potrebno inspicirati i utvrditi ispunjavaju li propisane GMP uvjete. Dodatni izazov za inspektorate i regulatora predstavljaju i nedavna otkrića nitrozaminskih onečišćenja kao potencijalnih karcinogena u određenim lijekovima, kao i pojava pandemije COVID-19, koja dodatno otežava putovanja inspektora u treće zemlje. Europsko zakonodavstvo u tim slučajevima omogućava postupanje koje uključuje ocjenu na daljinu, te se na taj način omogućuje kontinuirani nadzor proizvodnih mjesta i izbjegavaju potencijalne nestašice lijekova posebice u pandemijskom razdoblju. S obzirom na to da ocjena na daljinu ne može u potpunosti zamijeniti fizički nadzor nad proizvodnim mjestom, potrebno je detaljno razraditi smjernice za postupanje u takvim slučajevima.

\section{Popis kratica}

List of abbreviations

$$
\begin{array}{ll}
\text { CAPA } & - \text { Korektivne i popravne radnje } \\
& - \text { Corrective and Preventive Action } \\
\text { CHMP } & - \text { Povjerenstvo za humane lijekove } \\
& - \text { Committee for Human Medicinal Products } \\
\text { EDQM } & - \text { Europsko ravnateljstvo za kakvoću lijekova i } \\
& \text { zdravstvenu skrb } \\
& - \text { European Directorate for the Quality of } \\
& \text { Medicines \& Health Care } \\
\text { EMA } & - \text { Europska agencija za lijekove } \\
& - \text { European Medicines Agency } \\
\text { EN } & - \text { Europska norma } \\
& - \text { European Standard }
\end{array}
$$

EudraGMDP - EU baza podataka o proizvodnim dozvolama i GMP/GDP potvrdama

- European Union Data Base on manufacturing, authorisations and GMP/GDP certificates

FDA - Američka uprava za hranu i lijekove

- US Food and Drug Administration

GCP - Dobra klinička praksa

- Good Clinical Practice

GDP - Dobra praksa u prometu na veliko

- Good Distribution Practice

GLP - Dobra laboratorijska praksa

- Good Manufacturing Practice 
GMP

- Dobra proizvođačka praksa

- Good Laboratory Practice

HALMED - Agencija za lijekove i medicinske proizvode - Agency for Medicinal Products and Medical Devices

ISO

- Međunarodna organizacija za normizaciju

- International Organisation for Standardisation

OMCL - Službeni laboratorij za provjeru kakvoće lijekova

- Official Medicines Control Laboratory

PIC/S - Farmaceutsko-inspekcijsko-kooperacijska shema

- Pharmaceutical Inspection Co-operation Scheme

SOP

- Standardni operativni postupak

- Standard Operating Procedure

WHO - Svjetska zdravstvena organizacija

- World Health Organisation

\section{Literatura \\ References}

1. Zakon o lijekovima, Narodne novine, br. 76/2013.

2. Pravilnik o uvjetima za davanje proizvodne dozvole, zahtjevima dobre proizvođačke prakse te potvrdi o provođenju dobre proizvođačke prakse za lijekove, Narodne novine br. 83/2013.

3. Pravilnik o uvjetima i načinu utvrđivanja zahtjeva dobre proizvođačke prakse i dobre prakse u prometu na veliko djelatnih tvari te o postupku upisa u očevidnik proizvođača, uvoznika i veleprodaja djelatnih tvari i davanju potvrde o provođenju dobre proizvođačke prakse, Narodne novine, br. 83/2013.

4. DIREKTIVA 2001/83/EZ EUROPSKOG PARLAMENTA I VIJEĆA od 6. studenoga 2001. o zakoniku Zajednice o lijekovima za humanu primjenu, URL: https://eur-lex.europa. eu/legal-content/HR/TXT/PDF/?uri=CELEX:32001L0083\&from $=H R(28.6 .2020$.).

5. EudraLex - Volume 4 Good manufacturing practice (GMP) Guidelines, URL: https://ec.europa.eu/health/documents/ eudralex/vol-4_en (28. 6. 2020.).

6. Zakon o lijekovima i medicinskim proizvodima, Narodne novine, br. 121/2003.

7. Zakon o izmjenama i dopuni Zakona o lijekovima i medicinskim proizvodima Narodne novine, br. 107/2004.

8. Zakon o Izmjenama i dopunama Zakona o veterinarsko-medicinskim proizvodima, Narodne novine, br. 32/2019.

9. URL: http://www.halmed.hr/Novosti-i-edukacije/Novosti/2019/Obavijest-o-obvezi-prijave-izmjena-za-lijekove-koji-sadrzavaju-djelatne-tvari-kandesartan-irbesartan-losartan-olmesartan-i-valsartan-nastavno-na-Odluku-Europske-komisije-od-2-travnja-2019-vezano-uz-moguca-oneciscenja-N-nitrozaminima/2148/ (28. 6. 2020.).

10. URL: http://www.halmed.hr/Novosti-i-edukacije/Novosti/2019/Obavijest-o-detekciji-nitrozaminskih-oneciscen- ja-u-tragovima-u-malom-broju-lijekova-s-metforminom-izvan-Europske-unije/2251/ (28. 6. 2020.).

11. URL: http://www.halmed.hr/Novosti-i-edukacije/Novosti/2019/Europska-agencija-za-lijekove-zapocinje-ocjenu-lijekova-koji-sadrze-djelatnu-tvar-ranitidin-nakon-detekcije-NDMA/2205/ (28. 6. 2020.).

12. URL: https://english.cbg-meb.nl/latest/news/2020/07/09/ safety-of-paracetamol-is-not-compromised (28. 6. 2020.).

13. S. Tomić, A. Filipović Sučić, A. Plazonić, R. Truban Žulj, V. Macolić Šarinić, B. Čudina, A. llić Martinac, Regulating medicines in Croatia: the five years experience of the Agency for Medicinal products and Medical Devices, Croat. Med. J. 51 (2010) 104-112, doi: https://doi.org/10.3325/ cmj.2010.51.104.

14. S. Tomić, A. Filipović Sučić, A. Ilić Martinac, Good manufacturing practice: the role of local manufacturers and competent authorities, Arh. Hig. Rada Toksikol. 61 (2010) 425-436, doi: https://doi.org/10.2478/10004-1254-61-2010-2035.

15. S. Tomić, A. Filipović Sučić, A. Ilić Martinac, Reguliranje lijekova u Hrvatskoj - doprinos javnom zdravstvu, Kem. Ind. 59 (2010) 343-349.

16. I. Škrnjug, S. Uzeirbegović, M. L. Romčević, S. Tomić, H. Meyer, C. Conrad, Mutual recognition in the European system: A blueprint for increasing access to medicines? Regul. Toxicol. Pharmacol. 7 (2019) 270-277, doi: https://doi. org/10.1016/j.yrtph.2019.05.004.

17. Compilation of Community Procedures on Inspections and Exchange of Information, EMA/572454/2014 Rev 17, URL: https://www.ema.europa.eu/en/documents/regulatory-procedural-guideline/compilation-community-procedures-inspections-exchange-information_en.pdf (28. 6. 2020.).

18. PIC/S Secretariat GMP Inspection Reliance, PI 048-1, 2018 June 1, URL: https://picscheme.org/docview/2475 (28. 6. 2020.).

19. A. R. C. Geyer, V. D. Sousa, D. Silveira, Quality of medicines: Deficiencies found by Brazilian Health Regulatory Agency (ANVISA) on good manufacturing practices international inspections, PLoS One 13 (8) (2018), doi: https://doi. org/10.1371/journal.pone.0202084.

20. A. H. Stoimenova, B. J. Kirilov, S. R. Gueorguiev, E. S. Petkova-Gueorguieva, S. G. Ognianov, Good Manufacturing Practice for Medicinal Products in Bulgaria: an Analysis of Regulatory Inspection Findings, Folia Med. (Plovdiv) 62 (2020) 165-171. doi: https://doi.org/10.3897/folmed.62.e49802.

21. A. B. Pazhayattil, M. Ingram, N. Sayeed, A Quantitative Study of US FDA Inspection Data for Drug Manufacturing Sites, Ther. Innov. Regul. Sci. 54 (4) 2020 725-730. doi: https:// doi.org/10.1007/s43441-019-00015-3.

22. B. G. Gouveia, P. Rijo, T. S. Gonçalo, C. P. Reis, Good manufacturing practices for medicinal products for human use, J. Pharm. Bioallied. Sci. 7 (2015) 87-96, doi: https://doi. org/10.4103/0975-7406.154424

23. Q. Xuan, Z. Dong, M. Shao, To Set Up Norms for Drug Safety and Inspection: To Guarantee Administrative Sufficiency and Avoid Regulators from Being Wrongly Punished, Cell Biochem. Biophys. 73 (2015) 1-5, doi: https://doi.org/10.1007/ s12013-015-0568-x. 


\title{
SUMMARY
}

\section{COVID-19 Pandemic Alters Conventional Approach of Good Manufacturing Practice Inspection}

\author{
Teo Kolonić, Martina Bencetić Marijanović, and Siniša Tomić*
}

Good Manufacturing Practice (GMP) is a set of different guidelines, rules and standards that guarantee effectiveness, quality, safety and consistency in manufacturing and quality control of medicinal products. To maintain consistency in inspection standards, HALMED has in place a Quality Manual developed according to European guidelines. The Agency inspectors are trained and experienced accordingly, and are permanently educated. After an inspection has been completed, HALMED issues a manufacturing license and a GMP certificate for manufacturers located in the Republic of Croatia or a GMP certificate for manufacturers from third countries. Due to the pandemic situation that prevents inspectors to travel to manufacturing sites abroad, they proceed with the distant assessment of manufacturers.

\section{Keywords}

Agency for Medicinal Products and Medical Devices, inspection, good manufacturing practice, manufacturing license, deficiencies 